\title{
Cellular Factors Affecting Nitrogen Fixation in the Blue-Green Alga Chlorogloea fritschii
}

\author{
BY P. FAY, H. D. KUMAR AND G. E. FOGG \\ Department of Botany, Westfield College, University of London
}

(Received 30 December 1963)

\begin{abstract}
SUMMARY
Synchronous cultures of a nitrogen-fixing blue-green alga, hitherto known as Chlorogloea fritschii but more probably an anomalous species of the genus Nostoc, were obtained by a combination of light and temperature treatments. Variation in dimensions, dry weight, pigment content and total nitrogen content of cells was followed during the development of synchronous cultures. The nitrogen-fixing activity was greatest in the small-celled filaments which develop from the endospores and predominate during exponential growth of the alga in cultures of limited volume. Strains of the alga produced by repeated exposure to $\mathbf{X}$-rays, ultraviolet radiation, or sublethal concentrations of colchicine or urethane, were found to have lower rates of nitrogen fixation per unit dry weight than the original strain but liberated relatively more extracellular nitrogenous products.
\end{abstract}

\section{INTRODUCTION}

In the absence of an exogenous source of combined nitrogen the fixation of elementary nitrogen by blue-green algae normally parallels increase in cell material, any factor affecting growth having at least an approximately corresponding effect on nitrogen fixation. It must be envisaged, however, that the relation of nitrogen fixation to increase in total cell material is under genetic control; and it is attractive, although perhaps naive, to suppose that strains with especially pronounced capacities for nitrogen fixation may be obtained and used on the economic scale to increase the fertility of habitats such as rice-fields. Superimposed on the genetically determined relation there must be changes depending on the physiological condition of the cells and this will depend on endogenous factors as well as on environmental conditions. Work with synchronous cultures of Chlorella (Nihei et al., 1954) has shown that the metabolic characteristics of cells change during the division cycle and leads to the expectation that the capacity of a cell of a blue-green alga to fix nitrogen may vary considerably during its individual growth. This paper describes investigations into these possibilities carried out with the alga Chlorogloea fritschii, which was the subject of the previous communication in this series (Fay \& Fogg, 1962).

\section{METHODS}

Strain of alga, culture and general analytical methods. These were the same as in previous work (Fay \& Fogg, 1962) except that the medium used for the mutagenesis studies was that described by Fogg (1949) diluted to half the usual concentration.

Ultraviolet irradiation. A Hanovia $80 \mathrm{~cm} .30$ watt quartz-jacketed mercury lamp 
emitting mainly at $2537 \AA$. was used. Algal suspensions were exposed at a distance of $25 \mathrm{~cm}$. from the tube in open sterile Petri dishes with occasional agitation.

$X$-irradiation. The characteristics of the source and radiation were: $33 \mathbf{k V}_{\mathrm{p}}$, $25 \mathrm{~mA}$., $0.275 \mathrm{~mm}$.Al filtration, $3.1 \mathrm{~mm}$. wax half value thickness, dose rate $4250 \mathrm{r}$./min. Algal suspensions were exposed in Petri dishes covered with thin sterile 'Styrafoil-S', which transmits most of the radiation (Cosslett \& Nixon, 1960).

Pigment estimations. Chlorophyll and carotenoids were extracted by absolute methanol from fresh material that had been washed once in distilled water. After extraction for $10 \mathrm{~min}$. the suspension was centrifuged and the supernatant fluid decanted; a second extraction resulted in complete removal of chlorophyll and carotenoids. The two extracts were combined and made to known volume with methanol. Relative measures of chlorophyll concentration in the extracts were obtained by the determination of absorption at the $665 \mathrm{~m} \mu$ peak. For estimation of phycocyanin the material, having been washed in distilled water, was resuspended in distilled water and frozen at $-20^{\circ}$. A drop of chloroform was added and the material was allowed to autolyse at $5^{\circ}$ for a few days. A clear solution of phycocyanin was obtained by repeated extraction and centrifugation, making the combined extracts up to known volume. Absorption at $620 \mathrm{~m} \mu$ was used as a measure of the relative concentration of phycocyanin.

Tracer experiments. Uptake of ${ }^{15} \mathrm{~N}$ was determined according to Burris \& Wilson (1957). The algal suspensions were exposed to an atmosphere containing $N_{2}$, enriched with ${ }^{15} \mathrm{~N}$, in a closed culture apparatus. The samples were subjected to Kjeldahl digestion and distillation and the ammonium-N so produced was converted to elementary nitrogen in a Rittenberg tube. Mass analysis was carried out with a MS 3 type Associated Electrical Industries Ltd. mass-spectrometer.

\section{RESULTS}

\section{Variations in nitrogen-fixing capacity during the life-cycle}

The life-cycle. The starting point may be taken as the liberation of endospores which occurs soon after the transference to fresh medium of cells from a mature culture. The endospores remain adhering to each other after disruption of the parent cell-membrane, forming a short motile filament, usually 4-6 cells long, resembling the hormogonium as found in Nostocales and Stigonematales. The cells at stage I are pale blue-green in colour and from 2.5 to $3.5 \mu$ in diameter (Pl. 1, fig. 1 ). After their liberation, the cells grow in size, up to about $4.5 \mu$ in diameter, and become more deeply blue-green, dividing transversely so that the filamentous character is preserved (stage II; PI. 1, fig. 2). Later, cell diameter increases to about $6 \cdot 0 \mu$ and longitudinal divisions occur. The filamentous character then gradually disappears and the shape of the cells changes from round to polygonal as the size of the groups increases (stage III; Pl. 1, fig. 3). Finally (stage IV), the cell diameter increases to about $7 \cdot 2 \mu$, the contents become yellowish green and markedly granular, and endospores are formed by repeated divisions (PI. 1, fig. 4).

The course of growth and nitrogen fixation in cultures of limited volume. Growth and nitrogen fixation under optimum conditions $\left(35^{\circ}, 5000\right.$ metre-candles and continuous agitation) followed a normal course (Fig. 1). A lag phase of about 3 days was followed by exponential growth for about 7 days then by a period of declining 
relative growth leading into a stationary phase after about 30 days. During the course of growth the proportions of the various size-classes of cells changed so that the mean cell diameter decreased during exponential growth and increased in the post-exponential phases (Fig. 2). Cell nitrogen content on a dry weight basis changed in the opposite manner (Fig. 2), suggesting that the nitrogen-fixing capacity of the cells varied, those in the earlier stages of the life-cycle evidently being more active in this respect than those at a later stage. Further study of this possibility required more homogeneous populations of cells than can be obtained in cultures of this type.

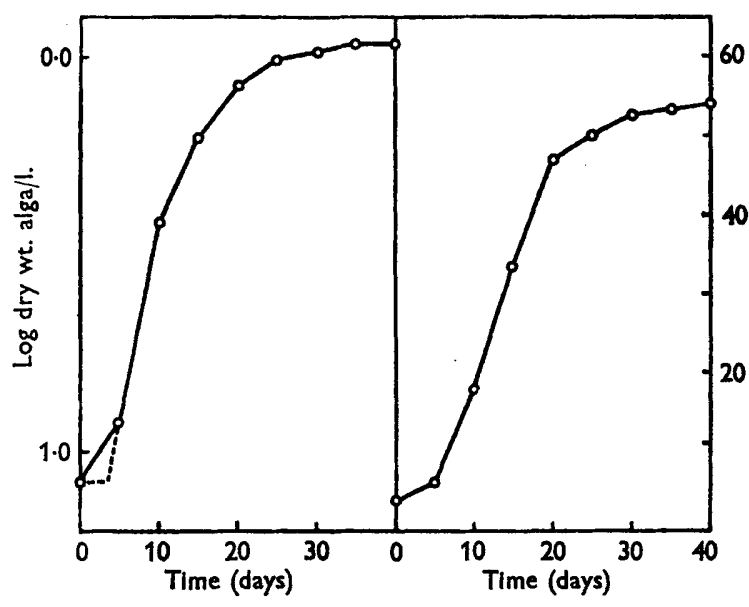

Fig. 1

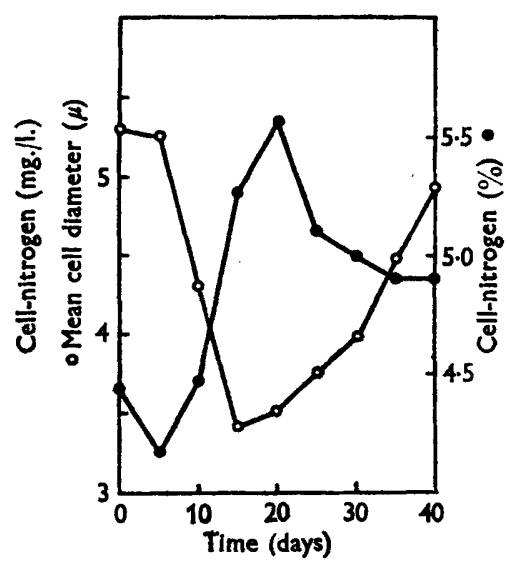

Fig. 2

Fig. 1. The course of growth of Chlorogloea fritschii in cultures of limited volume at $\mathbf{3 5}^{\circ}$ and 5000 metre-candles with continuous agitation. Left, dry wt.; right, total cellnitrogen.

Fig. 2. Changes in cell size $(O)$ and total cell-nitrogen as \% of dry wt. of alga (O) during growth of Chlorogloea fritschii in cultures of limited volume (see Fig. 1).

\section{Synchronous cultures}

The life-cycle of Chlorogloea fritschii is more complex than that of Chlorella and to obtain cultures in which the majority of cells are synchronized as regards stage in the life-cycle is correspondingly more difficult. Experiments already reported (Fay \& Fogg, 1962) showed that high light-intensity and high temperature favoured a high proportion of large mature cells, whereas at low light-intensity and low temperature the proportion of small cells was high. Synchronized cultures may thus be obtained by a combination of light and temperature treatments, a method similar to that used with Chlorella ellipsoidea by Tamiya (1961).

Cultivation of Chlorogloea fritschii at $35^{\circ}$ and about 5000 metre-candles for about 20 days resulted in $75-85 \%$ of the population being stage IV cells (PI. 1 , fig. 6). Transfer of a population rich in stage IV cells to fresh medium at a lower temperature $\left(\mathbf{2 5}^{\circ}\right.$ ) and a lower light intensity (about 300 metre-candles) resulted, after about 20 days, in cultures in which 75-85\% of the cells were in stage $I$ (Pl. 1, fig. 7). When populations rich in stage $I$ cells were transferred to fresh medium and 
the higher temperature and higher light intensity, they changed gradually and uniformly into stage IV-rich populations.

\section{Changes in cell characteristics in synchronized cultures}

Samples were withdrawn aseptically at 2- or 3-day intervals from synchronized cultures for determination of cell number, cell size, dry weight, cell nitrogen, chlorophyll and phycocyanin. The results are given in Figs. 3 and 4.

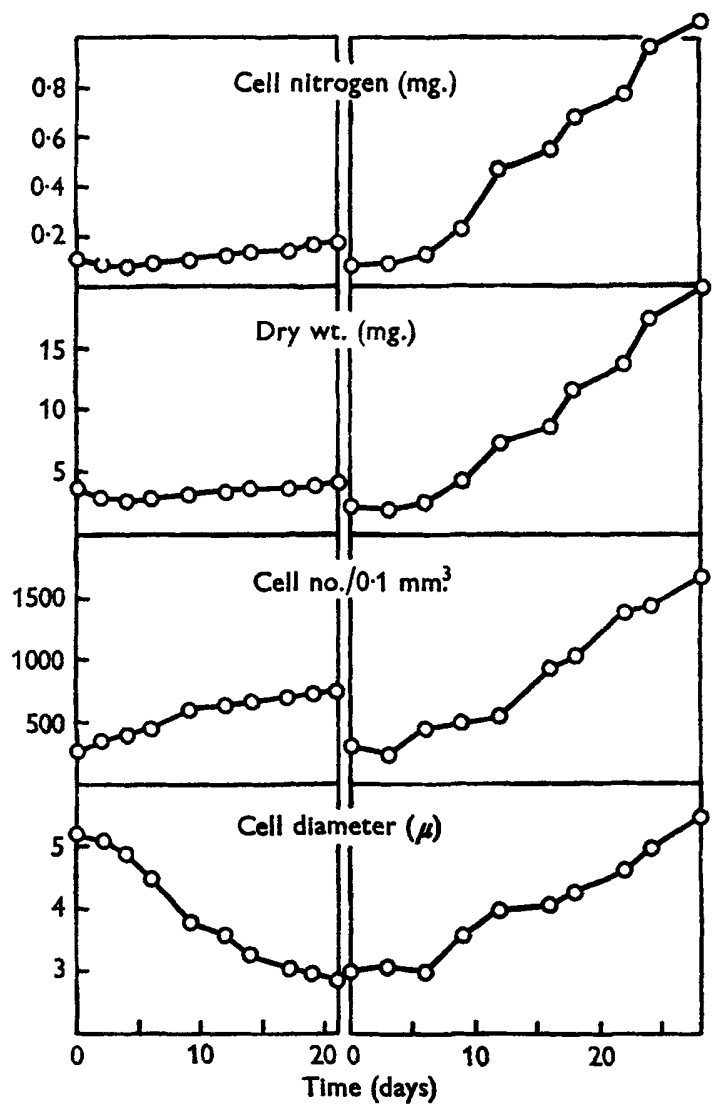

Fig. 3. Changes in cell size, cell number per $0.1 \mathrm{~mm} .{ }^{\mathrm{z}}$, dry wt. in $\mathrm{mg} .100 \mathrm{ml}$., and total cell-nitrogen in $\mathrm{mg}$. $/ 100 \mathrm{ml}$. in a synchronized culture of Chlorogloea fritschii. Left, transformation of stage IV to stage I; right, transformation from stage I to stage IV.

During the transformation from stage IV to I (Figs. 3 and 4, left-hand diagrams) there was an increase in cell numbers and a decrease in mean cell diameter, corresponding to the liberation of endospores. These changes were more rapid during the first 8 days than afterwards. Dry weight and cell nitrogen showed similar slight decreases following transference to fresh medium, an occurrence which has also been observed with Anabaena cylindrica (Fogg \& Than-Tun, 1960). After this, there was a slow rise in total dry weight and in cell nitrogen, the latter increasing relatively more as shown by an increase in cell nitrogen/unit dry weight of organism (Fig. 4). Both the chlorophyll and the phycocyanin content of the suspension increased about 


\section{Nitrogen fixation by Chlorogloea fritschii}

threefold, i.e. the amount of pigment per cell remained at about the same value throughout the experimental period. There was, however, a distinct lag in synthesis of phycocyanin as compared with that of chlorophyll.

The stage I material obtained in the above experiment was transferred to fresh medium at high temperature and high light-intensity for observation of the transformation to stage IV cells (Figs. 8 and 4 ; right-hand diagrams). The curve for increase in cell numbers shows fairly distinct steps, indicating four periods of more

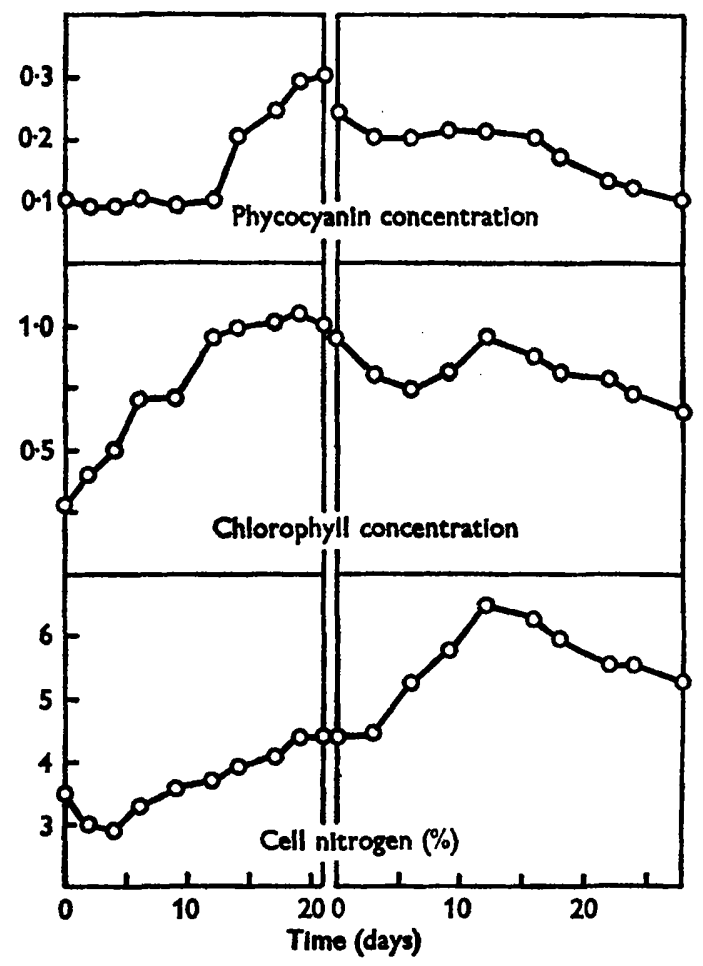

Fig. 4. Changes in cell nitrogen as $\%$ of dry wt. of alga and in chlorophyll and phycocyanin concentrations (arbitrary units) in a synchronized culture of Chlorogloea fritschii. Left, transformation of stage IV to stage I; right, transformation from stage I to stage IV.

or less synchronous cell divisions. The curves for cell nitrogen and dry weight also show steps but, initially at least, these are out of phase with those in cell number indicating, as one would expect, that synthesis of cell material was most vigorous in the intervals between cell divisions. The cells remained small for the first 6 days then their size increased fairly steadily until at the end of the 27-day period the mean diameter was about twice its initial value. Cell nitrogen/unit dry wt. of organism started at a low value, rose to a maximum at 12 days, then declined somewhat. The amounts of phycocyanin and chlorophyll/unit dry wt. remained at a nearly constant high value so long as the cell nitrogen/unit dry wt. was increasing, but thereafter declined. However, the amount of both pigments per cell remained at an approximately constant value throughout the period of the experiment. 


\section{Effects of mutagenic agents on growth and nitrogen fixation}

It has so far proved impossible to grow Chlorogloea fritschii from single cells on solid media, so that the usual microbiological techniques for recognizing and isolating mutants cannot be applied. Consequently our procedure was to give repeated massive mutagenic treatments with the object of obtaining genetically distinct resistant strains. Kumar (1963) was successful in producing in this way distinct strains of another blue-green alga, Anacystis nidulans, which are stable over many subcultures.

The following treatments were given:

(1) .5 successive irradiations with X-rays, of $100,000-150,000 \mathrm{r}$. each time, the alga being subcultured in between irradiations;

(2) 15 successive $10 \mathrm{~min}$. exposures to ultraviolet radiation, the alga being subcultured in between exposures;

(3) 5 successive subcultures in a medium containing $10-20 \mathrm{mg}$. colchicine/100 ml., followed by another 5 subcultures in medium containing $40 \mathrm{mg}$. colchicine $/ 100 \mathrm{ml}$;

(4) 5 successive subcultures in a medium containing $10-250 \mathrm{mg}$. urethane/100 ml., followed by another 10 in medium containing $500 \mathrm{mg}$. urethane $/ 100 \mathrm{ml}$.

Table 1. Comparison of nitrogen contents of five strains of Chlorogloea fritschii

\begin{tabular}{|c|c|c|c|c|c|c|c|}
\hline \multirow[b]{2}{*}{ Strain } & \multicolumn{2}{|c|}{ Values per $200 \mathrm{ml}$. culture suspension (mean values in parentheses) } & $\begin{array}{r}\text { ml. cul } \\
\mathbf{N} \text { co }\end{array}$ & $\begin{array}{l}\text { re suspension } \\
\text { ent of alga }\end{array}$ & mean values in & renthe & \\
\hline & $\begin{array}{c}\text { Age } \\
\text { (days) }\end{array}$ & $\begin{array}{c}\text { Dry wt. } \\
\text { of alga } \\
\text { (mg.) }\end{array}$ & mg. & $\begin{array}{l}\text { mg./100 mg. } \\
\text { dry wt. alga }\end{array}$ & $\begin{array}{l}\mathbf{N} \text { content of } \\
\text { culture filtrate }\end{array}$ & mg. & $\begin{array}{l}\text { mg. } / 100 \mathrm{mg} . \\
\text { dry wt. alga }\end{array}$ \\
\hline X-rayed & 21 & $\begin{array}{l}18 \cdot 5 \\
19 \cdot 0\end{array}$ & $\begin{array}{l}0 \cdot 662 \\
0 \cdot 726\end{array}$ & $\begin{array}{l}3.58 \\
3.82\end{array}(3 \cdot 70)$ & $\begin{array}{l}0.043 \\
0 \cdot 058\end{array}(0 \cdot 051)$ & $\begin{array}{l}0.705 \\
0 \cdot 784\end{array}$ & $\begin{array}{l}3.81 \\
4 \cdot 12\end{array}(3.97)$ \\
\hline Control & 21 & $\begin{array}{l}10 \cdot 2 \\
12 \cdot 6\end{array}$ & $\begin{array}{l}0 \cdot 418 \\
0 \cdot 500\end{array}$ & $\begin{array}{l}4.09 \\
3.97 \\
(4.08)\end{array}$ & - & - & 一 \\
\hline Control & 14 & $\begin{array}{l}12 \cdot 5 \\
11 \cdot 9\end{array}$ & $\begin{array}{l}0 \cdot 614 \\
0 \cdot 608\end{array}$ & $\begin{array}{l}4 \cdot 91 \\
5 \cdot 02\end{array}(4 \cdot 96)$ & $\begin{array}{l}0.022 \\
0.016\end{array}(0.019)$ & $\begin{array}{l}0 \cdot 636 \\
0 \cdot 624\end{array}$ & $\begin{array}{l}5 \cdot 09 \\
5 \cdot 24\end{array}(5 \cdot 16)$ \\
\hline $\begin{array}{l}\text { Gtraviolet } \\
\text { irradiated }\end{array}$ & 14 & $\begin{array}{r}10 \cdot 3 \\
7 \cdot 2\end{array}$ & $\begin{array}{l}0 \cdot 620 \\
0 \cdot 205\end{array}$ & $\begin{array}{l}6 \cdot 02 \\
2 \cdot 85\end{array}(4 \cdot 44)$ & $\begin{array}{l}0.052 \\
0.049\end{array}(0.051)$ & $\begin{array}{l}0.672 \\
0.254\end{array}$ & $\begin{array}{l}6 \cdot 52 \\
3.53\end{array}(5 \cdot 03)$ \\
\hline $\begin{array}{l}\text { Colchicine } \\
\text { treated }\end{array}$ & 14 & $\begin{array}{l}13 \cdot 7 \\
11 \cdot 4\end{array}$ & $\begin{array}{l}0.561 \\
0.529\end{array}$ & $\begin{array}{l}4 \cdot 09 \\
4 \cdot 55\end{array}(4 \cdot 32)$ & $\begin{array}{l}0.070 \\
0.058\end{array}(0.064)$ & $\begin{array}{l}0 \cdot 631 \\
0.587\end{array}$ & $\begin{array}{l}4 \cdot 61 \\
5 \cdot 15\end{array}(4 \cdot 88)$ \\
\hline Urethane & 14 & $\begin{array}{l}12 \cdot 3 \\
12 \cdot 3\end{array}$ & $\begin{array}{l}0.533 \\
0.545\end{array}$ & $\begin{array}{l}4 \cdot 33 \\
4 \cdot 43\end{array}(4 \cdot 38)$ & $\begin{array}{l}0.061 \\
0.058\end{array}(0.060)$ & $\begin{array}{l}0.594 \\
0 \cdot 603\end{array}$ & $\begin{array}{l}4 \cdot 83 \\
4 \cdot 90\end{array}$ \\
\hline
\end{tabular}

Before comparing them, the 4 strains so obtained and the untreated strain were subcultured, without irradiation or other treatment, in basal medium. This was repeated after 7 days and $0.5 \mathrm{ml}$. portions taken as inocula from these cultures after a further 7 days. The experimental cultures were $100 \mathrm{ml}$. in volume and were incubated at $35^{\circ}$ with occasional shaking. After 14 or 21 days the cultures were harvested and the dry weight of alga and the nitrogen content of cells and medium determined. The results are presented in Table 1. Growth in terms of the total dry wt. of cell material per culture was about the same for the control, ultraviolet-, colchicine- and urethane-treated strains, but growth of the X-ray-treated strain appeared somewhat better than that of the control. However, for 3 treated strains, and perhaps also for the fourth (ultraviolet-treated), the nitrogen content on a dry 
weight basis was less and the proportion of extracellular combined nitrogen more, than for the untreated strain.

A strain produced by 40 successive $10 \mathrm{~min}$. exposures to ultraviolet radiation and subculturings was compared with the untreated strain by using the ${ }^{15} \mathrm{~N}$ isotope of nitrogen as a means of determining nitrogen fixation. Each strain was grown under optimum conditions; then the cells were suspended in fresh medium and exposed to an atmosphere with $0.2 \mathrm{~atm} . \mathrm{N}_{2}$ enriched with $7 \%(\mathrm{v} / \mathrm{v})^{15} \mathrm{~N}, 0.2 \mathrm{~atm} . \mathrm{O}_{2}, 0.05 \mathrm{~atm}$. carbon dioxide and 0.55 atm. argon. The cells were incubated at $30^{\circ}$ and 3000 metre-candles with continuous agitation by a magnetic stirrer for 3 days. The nitrogen-fixing capacity of the treated and control strains was compared in terms of the atom $\%$ excess ${ }^{15} \mathrm{~N}$ in the cell material (Table 2). The rate of incorporation of ${ }^{15} \mathrm{~N}$ by the ultraviolet resistant strain was slightly less than that by the untreated strain. This agrees with the results reported above obtained by the conventional micro-Kjeldahl method.

Table 2. Comparison of ${ }^{15} \mathrm{~N}$ uptake by untreated and ultraviolet-irradiated strains of Chlorogloea fritschii after 3 days exposure in the light to elementary nitrogen enriched with $7 \%{ }^{15} \mathrm{~N}$

\begin{tabular}{|c|c|c|}
\hline Sample & Atom $\%{ }^{15} \mathrm{~N}$ & Atom $\%{ }^{15} \mathbf{N}$ excess \\
\hline Standard $\left(\mathrm{NH}_{4}\right)_{2} \mathrm{SO}_{4}$ & $0 \cdot 362$ & - \\
\hline $\begin{array}{r}\text { Untreated strain (1) } \\
(2)\end{array}$ & $\begin{array}{l}0.545 \\
0.541\end{array}(0.543)^{*}$ & $\begin{array}{l}0 \cdot 183 \\
0 \cdot 179\end{array}(0 \cdot 181)$ \\
\hline $\begin{array}{l}\text { U.v.-treated } \\
\text { strain }\end{array}$ & $\begin{array}{l}0.534 \\
0.537 \\
(0.536)\end{array}$ & $\begin{array}{l}0 \cdot 172 \\
0 \cdot 175\end{array}(0 \cdot 174)$ \\
\hline
\end{tabular}

\section{DISCUSSION}

Chlorogloea fritschii was described as a new species by Mitra (1950) and referred to the Entophysalidaceae, order Chroococcales, which includes unicellular or colonial, non-heterocystous, blue-green algae. However, our material (Cambridge Culture Collection, no. 1411/1) when grown in medium free from combined nitrogen, produces distinct filaments and heterocysts at certain stages (Pl. 1, fig. 5). The presence of combined nitrogen is known to suppress heterocyst formation (Fogg, 1949) and the state of affairs in $C$. fritschii resembles that in another filamentous blue-green alga, Camptylonema lahorense (Kumar, 1962), which is generally devoid of heterocysts in the early stages of growth in Chu no. 10 medium but which, according to Pande \& Mitra (1961), produces them in nitrogen-deficient media. In view of these findings $C$. fritschii can no longer be regarded as a member of the Chroococcales. Dr J. W. G. Lund, who has kindly examined our material, has expressed the tentative opinion that it is a Nostoc (personal communication).

This view is supported by the resemblance of the life-cycle of Chlorogloea fritschii to that of Nostoc muscorum as described by Lazaroff \& Vishniac (1961). These authors reported an alternation of coccoid ('aseriate') and filamentous stages, successive cell divisions producing a cluster of cells surrounded by a membrane which later breaks down liberating the hormogonia. When $N$. muscorum is grown in the dark on an organic substrate, the life-cycle is interrupted at the aseriate stage and, by exposing such a culture to low-intensity light, synchronous cell division may 
be induced. The main difference between this life-cycle and that of $C$. fritschii is that in the latter the filamentous habit is only evident in the early stages.

The life-cycle of Chlorogloea fritschii comprises several cell generations and is more elaborate than that of Chlorella spp., which is completed in one division cycle. Nevertheless, comparison with the cycle in Chlorella, as described by Hase (1962) and Tamiya (1963), is worthwhile. Our results give little information about variations in metabolic activity during the division cycle in $C$. fritschii but there seem to be resemblances between certain stages in the life-cycle of this species and stages in the division cycle of Chlorella. In their small size and high pigment content stage II cells correspond to $D_{2}$ cells of Chlorella. This is the phase of most active nitrogen fixation and, according to Tamiya et al. (1953), the nitrogen content of Chlorella ellipsoidea is highest in the $\mathrm{D}_{\mathrm{a}}$ stage. In their large size, low pigment content and low nitrogen content, stage IV cells of Chlorogloea resemble $L$ cells of Chlorella. As in nearly all studies with synchronous cultures (Maaløe, 1962) there is uncertainty as to how far the changes observed with $C$. fritschii are artefacts due to the treatment used to induce synchronous division. Repetition of the pattern in a second growth cycle would be an indication that it is correlated with the normal growth cycle, but this has not yet been achieved.

It is to be expected a priori that mutation is more likely to reduce the efficiency of a complex process such as nitrogen fixation than to enhance it. Mutants of Azotobacter in which nitrogen fixation or associated processes are impaired have been obtained (e.g. Green, Alexander \& Wilson, 1953; Mumford, Carnahan \& Castle, 1959) but no mutants with increased nitrogen-fixing powers appear to have been described, although here the difficulty of devising a technique for selecting such mutants must be borne in mind. Increase in the relative activity of the fixation process itself will result in a greater amount of nitrogen fixed per unit amount of growth, e.g. increase in dry weight. The four strains of Chlorogloea fritschii studied by us all fixed no more, or less, nitrogen per unit dry wt. of organism than the wild type and our results are thus in accordance with expectation. Singh (1957) has reported an X-ray-induced mutant of Mastigocladus laminosus with increased nitrogen-fixing capacity but it is not clear whether nitrogen fixation was increased in the above sense. An increase in final yield of cell material without an increase in the relative rate of nitrogen fixation will, of course, lead to a greater total fixation, as it did in the test of our X-irradiated strain (Table 1). We have not investigated this instance further, but it might well depend on some quite trivial circumstance as, for example, the greater production of extracellular materials capable of forming complexes with inorganic ions (Fogg \& Westlake, 1955) leading to a greater availability of trace elements and this to a longer period of growth. In any case, conditions affecting rates of growth and yields are likely to be different in laboratory cultures and in the field, so that a strain which shows high nitrogen-fixing capacity or high yields in laboratory culture would not necessarily be of practical use in increasing the fertility of agricultural land. However, an increased production of extracellular nitrogenous products, such as observed with all four of our treated strains, might be of value if, as seems possible from the work of Allen and Arnon (see Arnon, 1958), these products are more or less directly assimilated by crop plants such as rice. 


\section{Nitrogen fixation by Chlorogloea fritschii}

This work was assisted by grants from the Nuffield Foundation and from the Department of Scientific and Industrial Research. The X-ray treatments were carried out in the Department of Anatomy, University College London, through the courtesy of Professor J. Z. Young, F.R.S. We are grateful to Mr P. Venning for help with the irradiations. Our thanks must also be expressed to the Commonwealth Scholarship Commission in the United Kingdom for the award of a scholarship, during the tenure of which this work was carried out, to one of us (H.D. K.).

This paper is number IV in the series 'Studies on nitrogen fixation by blue-green algae'.

\section{REFERENCES}

ARNon, D. I. (1958). The role of micronutrients in plant nutrition with special reference to photosynthesis and nitrogen assimilation. Trace Elements. Ed. by C. A. Lamb, O. G. Bentley \& J. M. Beattie, p. 1. New York: Academic Press.

Burris, R. H. \& Wilson, P. W. (1957). Methods for measurement of nitrogen fixation. Methods in Enzymology. Ed. by S. P. Colowick \& N. O. Kaplan, vol. 4, p. 355. New York: Academic Press.

Cosslett, V. E. \& Nixon, W. C. (1960). X-ray Microscopy. Cambridge University Press.

FAY, P. \& FogG, G. E. (1962). Studies on nitrogen fixation by blue-green algae. III. Growth and nitrogen fixation in Chlorogloea fritschii Mitra. Arch. Mikrobiol. 42, 310.

FoGG, G. E. (1949). Growth and heterocyst production in Anabaena cylindrica Lemm. II. In relation to carbon and nitrogen metabolism. Ann. Bot., Lond., N.S., 13, 241.

FogG, G. E. \& Than-Tun (1960). Interrelations of photosynthesis and assimilation of elementary nitrogen in a blue-green alga. Proc. roy. Soc. B, 153, 111.

FogG, G. E. \& WESTLAKE, D. F. (1955). The importance of extracellular products of algae in freshwater. Verh. int. Ver. Limnol. 12, 219.

Green, M., Alexander, M. \& Wilson, P. W. (1953). Hydrogenase in nitrogenasedeficient Azotobacter mutants. Proc. Soc. exp. Biol., N.Y. 82, 361.

HASE, E. (1962). Cell division. Physiology and Biochemistry of Algae. Ed. by R. A. Lewin, p. 617. New York: Academic Press.

Kumar, H. D. (1962). Observations on the developmental variability of Camptylonema lahorense Ghose. Hydrobiologia, $20,356$.

Kumar, H. D. (1963). The effects of mutagenic agents on blue-green algae. Ph.D. Thesis, University of London.

LazarofF, N. \& Vishniac, W. (1961). The effect of light on the developmental cycle of Nostoc muscorum, a filamentous blue-green alga. J. gen. Microbiol. 25, 365.

MAALøE, O. (1962). Synchronous growth. In The Bacteria. Ed. by I. C. Gunsalus \& R. Y. Stanier, vol. 4, p. 1. New York: Academic Press.

Mrtra, A. K. (1950). Two new algae from Indian soils. Ann. Bot., Lond., N.S. 14, 457.

Mumford, F. E., Carnahan, J. E. \& Castle, J. E. (1959). Nitrogen fixation in a mutant of Azotobacter vinelandii. J. Bact. 77, 86.

Ninei, T., Sasa, T., Mryachi, S., Suzuki, K. \& Tamiya, H. (1954). Change of photosynthetic activity of Chlorella cells during the course of their normal life cycle. Arch. Mikrobiol. 21, 155.

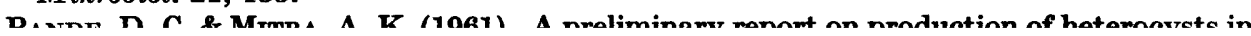




\section{EXPLANATION OF PLATE 1}

Phase-contrast photomicrographs of living material of Chlorogloea fritschii, illustrating its lifecycle. Fig. 1, stage I; Fig. 2, stage II; Fig. 8, stage III; Fig. 4, stage IV; Fig. 5, filaments with heterocysts; Fig. 6, stage IV starting material for synchronous culture; Fig. 7, synchronized population of stage $I$ cells $($ all $\times \mathbf{5 4 0})$. 

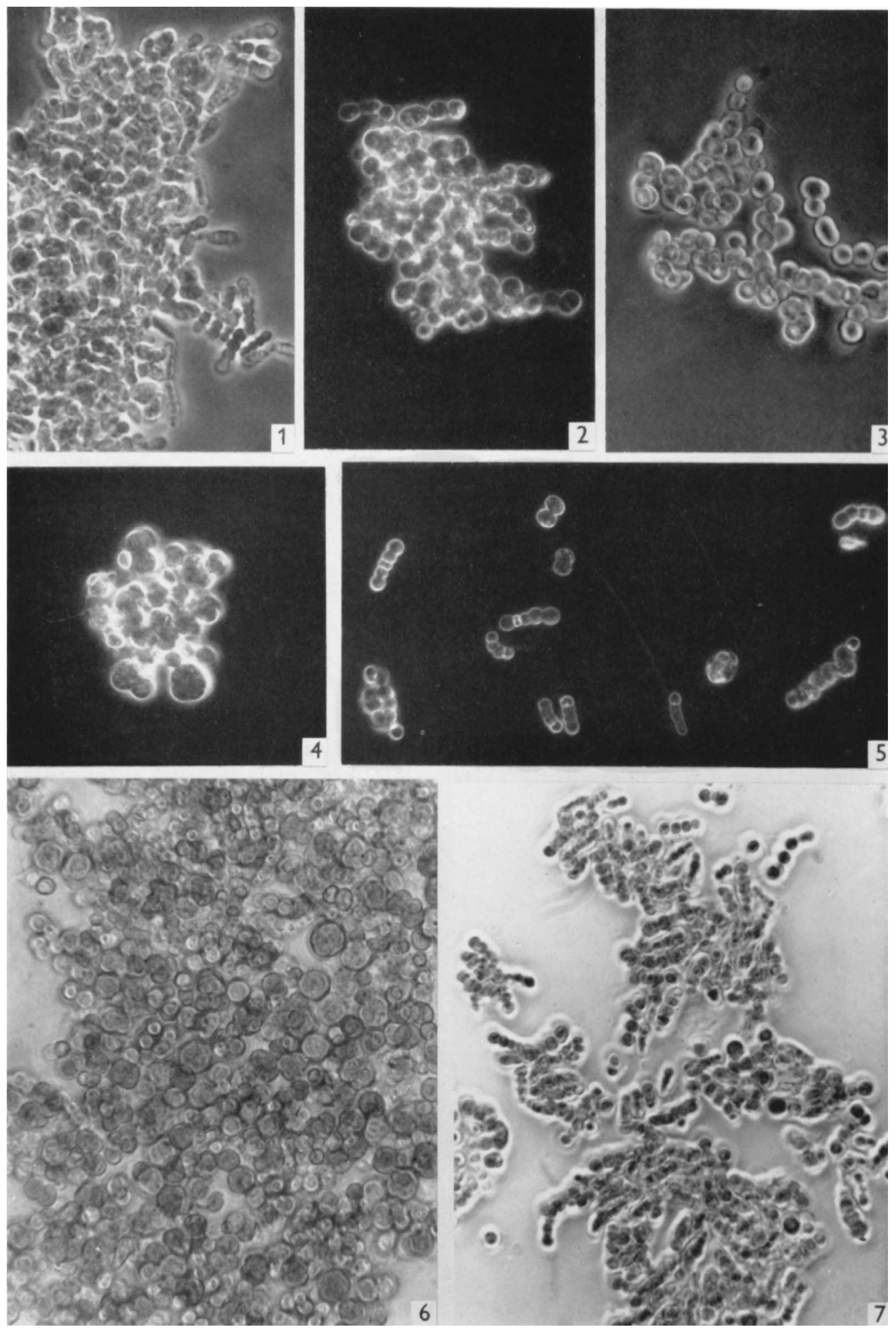